\title{
Raynaud's phenomenon as an interdisciplinary problem
}

\section{Objaw Raynauda jako problem interdyscyplinarny}

\author{
Karolina Górska', Aneta Szczerkowska-Dobosz', Dorota Purzycka-Bohdan', Marta Stawczyk-Macieja', \\ Karol Wierzba², Roman J. Nowicki'
}

'Department of Dermatology, Venereology and Alergology, Medical University of Gdansk, Poland

${ }^{2}$ Clinic of Internal Diseases, Connective Tissue Diseases and Geriatrics, Medical University of Gdansk, Poland

'Klinika Dermatologii, Wenerologii i Alergologii Gdańskiego Uniwersytetu Medycznego, Polska

${ }^{2}$ Klinika Chorób Wewnętrznych, Chorób Tkanki Łącznej i Geriatrii Gdańskiego Uniwersytetu Medycznego, Polska

\section{CORRESPONDING AUTHOR/ ADRES DO KORESPONDENCJI: \\ lek. Karolina Górska \\ Klinika Dermatologii, Wenerologii \\ i Alergologii \\ Gdański Uniwersytet Medyczny \\ ul. Kliniczna 1 a \\ 80-402 Gdańsk, Polska \\ tel.: +48 692206366 \\ e-mail: kagorska@uck.gda.pl}

\begin{abstract}
Raynaud's phenomenon is one of the most common disorders of the blood vessels, which usually affects fingers and toes. Raynaud's disease, also called primary Raynaud's phenomenon, is diagnosed when the cause is unknown, whereas Raynaud's syndrome or secondary Raynaud's phenomenon occurs as a skin manifestation of concomitant disease. The most common trigger is exposure to cold. Specific clinical features allow a quick diagnosis. Raynaud's phenomenon usually does not require pharmacologic treatment, but in some cases symptoms are severe and pharmacotherapy is necessary. Calcium channel blockers are usually used as a first-line treatment. Alternative forms of therapy include angiotensin-converting-enzyme inhibitors, $\alpha 1$-adrenergic blockers, phosphodiesterase- 5 inhibitors, endothelin antagonists, nitrates, antioxidants, statins, botulinum toxin, and even autologous fat grafting.
\end{abstract}

\section{STRESZCZENIE}

Objaw Raynauda jest jedną z najczęstszych reakcji skurczowych naczyń krwionośnych, zazwyczaj dotyczy palców rąk i stóp. Choroba Raynauda, inaczej zwana pierwotnym objawem Raynauda, jest rozpoznawana, gdy przyczyna schorzenia jest nieznana. Zespół Raynauda lub wtórny objaw Raynauda współtowarzyszy innym chorobom. Najczęstszym czynnikiem prowokującym skurcz naczyń jest ekspozycja na zimno. Charakterystyczny obraz kliniczny zwykle pozwala na szybkie ustalenia rozpoznania. Objaw Raynauda u większości chorych nie wymaga leczenia farmakologicznego, ale u niektórych osób objawy są nasilone i farmakoterapia staje się niezbędna. Leki z grupy antagonistów wapnia są często stosowane w leczeniu pierwszego rzutu. Alternatywne formy terapii obejmują: inhibitory konwertazy angiotensyny, leki $\alpha 1$-adrenergiczne, inhibitory fosfodiesterazy 5, antagonistów endoteliny, azotany, przeciwutleniacze, statyny, toksynę botulinową, a nawet autologiczne przeszczepy tkanki tłuszczowej.

Key words: treatment, capillaroscopy, Raynaud's phenomenon, Raynaud's disease, Raynaud's syndrome.

Słowa kluczowe: leczenie, kapilaroskopia, objaw Raynauda, choroba Raynauda, zespół Raynauda. 


\section{INTRODUCTION}

Raynaud's phenomenon is a vasoconstriction accompanied by changes in skin colour as a response to different triggers, such as cold or stress. We present a review of clinical presentation, diagnosis and treatment of Raynaud's phenomenon.

\section{CLINICAL PRESENTATION AND DIAGNOSIS OF RAYNAUD'S PHENOMENON}

Raynaud's phenomenon was first described in 1862 by Maurice Raynaud as local asphyxia of the extremities caused by an abnormal response of the central nervous system [1]. Almost 70 years later, Lewis suggested that the disorder is a result of digital vasoconstriction [2]. The pathophysiology of Raynaud's phenomenon is not yet fully understood. Peripheral mechanisms are considered to be primarily involved in the vasospastic reaction to different factors, including low temperature and emotional stress.

Raynaud's phenomenon affects most commonly women in early adulthood [3]. The prevalence of Raynaud's phenomenon, which varies by gender and geographical region, is around 3\% to $5 \%$ in most population studies [4-6]. In $80 \%$ to $90 \%$ of cases primary Raynaud's phenomenon is diagnosed. Acrocyanosis and erythema of digits should be considered in the differential diagnosis [7].

The pathophysiological background of Raynaud's phenomenon is still unknown. The main mechanisms inducing Raynaud's phenomenon are increased vasospasm and reduced vasodilatation, structural abnormality of the vessels, and coagulopathy. Therefore, endothelin-1, nitric oxide (NO), calcitonin gene-related peptide (CGRP), $\alpha 2$-adrenoceptor, free radicals, and platelet activation are the main factors contributing to these processes. Gaining a better understanding of the pathophysiology of Raynaud's phenomenon will lead to a more effective approach to targeted therapy [8].

There is no strict worldwide accepted definition of Raynaud's phenomenon, which may have an impact on patients' classification [6]. Nevertheless, to date, Raynaud's phenomenon is classified as primary Raynaud's phenomenon or Raynaud's disease and secondary Raynaud's phenomenon or Raynaud's syndrome. Primary Raynaud's phenomenon is an idiopathic, benign condition without any underlying disorder. It is characterized by a symmetrical presentation of symptoms, absence of tissue necrosis and negative result of the serum test for antinuclear antibodies (ANA). Secondary Raynaud's phenomenon is defined as a manifestation of a co-existing disorder, usually connective tissue disease. The most common one is systemic sclerosis. Raynaud's syndrome occurs

\section{WPROWADZENIE}

Objawem Raynauda nazywa się skurcz naczyń krwionośnych ze zmianą zabarwienia skóry, następujący w reakcji na różne czynniki, m.in. zimno lub stres. W pracy przedstawiono przegląd objawów klinicznych, diagnostykę oraz leczenie objawu Raynauda.

\section{OBJAWY KLINICZNE I DIAGNOSTYKA OBJAWU RAYNAUDA}

Nazwa schorzenia pochodzi od Maurice'a Raynauda, który w 1862 r. pierwszy opisał miejscową zamartwicę kończyn wywołaną nieprawidłową reakcją ośrodkowego układu nerwowego [1]. Niemal 70 lat później Lewis zasugerował, że objaw Raynauda jest skutkiem skurczu naczyń krwionośnych w obrębie palców [2]. Patofizjologia objawu Raynauda nie została w pełni poznana. Uważa się, że skurcz naczyń w reakcji na różne czynniki, m.in. niską temperaturę i stres emocjonalny, jest skutkiem działania mechanizmów obwodowych.

Objaw Raynauda występuje zwykle u kobiet w okresie wczesnej dorosłości [3]. W większości badań częstość występowania objawu Raynauda w zależności od płci i regionu geograficznego wynosi od ok. 3\% do 5\% [4-6]. W 80-90\% przypadków rozpoznaje się pierwotny objaw Raynauda. W diagnostyce różnicowej należy uwzględnić akrocyjanozę oraz rumień palców [7].

Podłoże patofizjologiczne objawu Raynauda nadal jest nieznane. Główny mechanizm objawu Raynauda obejmuje nasilony skurcz i zwężenie naczyń krwionośnych, nieprawidłowości strukturalne w obrębie naczyń oraz koagulopatię. W procesach tych biorą udział następujące czynniki: endotelina 1, tlenek azotu (NO), peptyd zależny od genu kalcytoniny (CGRP), receptor adrenergiczny $\alpha 2$, wolne rodniki oraz aktywacja płytek. Poszerzenie wiedzy o patofizjologii objawu Raynauda umożliwi opracowanie bardziej skutecznego podejścia do terapii celowanej tego schorzenia [8].

Nie opracowano dotąd ścisłej, uznanej na świecie definicji objawu Raynauda, która wpływa na klasyfikację pacjentów [6]. Aktualny podział objawu Raynauda obejmuje: pierwotny objaw Raynauda, zwany chorobą Raynauda, oraz wtórny objaw Raynauda, znany jako zespół Raynauda. Pierwotny objaw Raynauda jest łagodnym, idiopatycznym schorzeniem, niezwiązanym z żadną chorobą podstawową. Cechuje się symetrycznie rozmieszczonymi objawami, brakiem martwicy tkanek oraz ujemnym wynikiem badania w kierunku przeciwciał przeciwjądrowych (ANA) w surowicy. Wtórny objaw Raynauda współistnieje $\mathrm{z}$ innym schorzeniem, zwykle chorobą tkanki 
in an estimated $95 \%$ cases of systemic sclerosis and presents the first manifestation in $70 \%$ of patients diagnosed with this illness. Clinical findings that may indicate secondary Raynaud's phenomenon include sclerodactyly, calcinosis and fibrosis, ulcerations and abnormalities in capillaroscopic examination [9].

The best documented factor leading to the development of symptoms is exposure to cold. Some data indicate that the severity of symptoms depends even on age and body mass index (BMI) [10]. Furthermore, several personal factors, such as younger age, female gender, genetic factors, smoking habits, anxiety, and stress increase the risk of Raynaud's phenomenon [11]. In addition, a positive link with other vasospastic conditions, such as migraine, has been observed [6].

Clinically Raynaud's phenomenon is characterized by triphasic skin colour change: pallor (ischaemia) (Fig. 1), painful cyanosis (deoxygenation) (Fig. 2) and erythema (reperfusion) phase (Fig. 3) [1]. The diagnosis is based on the history of at least two skin colour changes in the fingers $[9,12]$. Raynaud's phe-

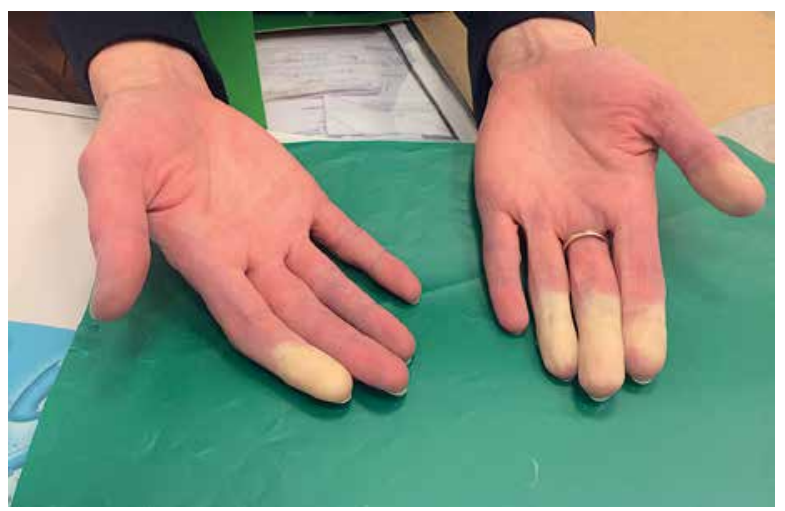

Figure I. Female patient, phase I of Raynaud's phenomenon, pallor of distal digits due to rapid vessel constriction

Rycina I. Pacjentka, faza I objawu Raynauda, zblednięcie dystalnych części palców rąk w przebiegu gwattownego skurczu naczyń łącznej. Najczęściej występuje z twardziną układową. Szacuje się, że objaw Raynauda towarzyszy ok. 95\% przypadków twardziny układowej i jest pierwszym objawem aż u 70\% pacjentów z tą chorobą. Wśród objawów klinicznych mogących wskazywać na wtórny objaw Raynauda należy wymienić: sklerodaktylię, kalcynozę i włóknienie, owrzodzenia oraz nieprawidłowości w badaniu kapilaroskopowym [9].

Najlepiej potwierdzonym czynnikiem wywołującym objawy jest ekspozycja na zimno. Niektóre dane wskazują, że nasilenie objawów zależy od wieku oraz wskaźnika masy ciała (BMI) [10]. Postuluje się, że na wzrost ryzyka rozwoju objawu Raynauda wpływają czynniki osobnicze, takie jak młodszy wiek, płeć żeńska, podatność genetyczna, palenie tytoniu, stany lękowe i stres [11]. Stwierdzono dodatnią korelację między objawem Raynauda i innymi schorzeniami, w których występuje skurcz naczyń krwionośnych, m.in. migreną [6].

W obrazie klinicznym objawu Raynauda można wyróżnić trzy fazy zmian zabarwienia skóry: zblednięcie (faza niedokrwienia) (ryc. 1), bolesne zasinie-

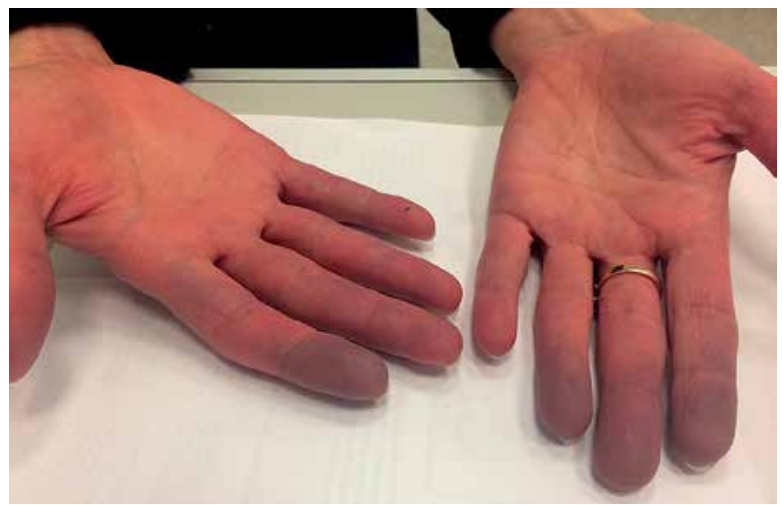

Figure 2. The same patient, phase II of Raynaud's phenomenon, subsequent cyanotic discolouration of fingers

Rycina 2. Ta sama pacjentka, faza II objawu Raynauda, następcza sinicza zmiana barwy palców rąk

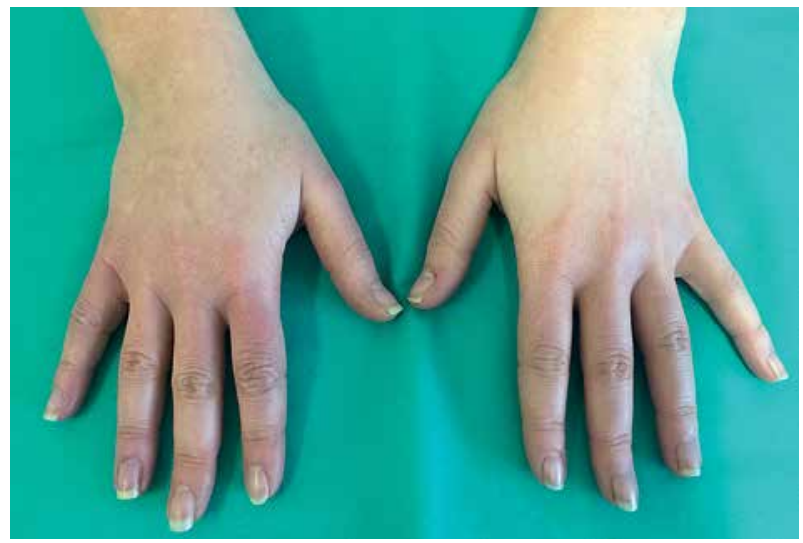

Figure 3. Another patient, phase III of Raynaud's phenomenon, erythema of fingers caused by reperfusion of blood

Rycina 3. Inna pacjentka, faza III objawu Raynauda, zaczerwienienie palców spowodowane reperfuzja knwi 
nomenon cannot be identified in patients presenting only an ischemic phase [13].

A major clinical locations of the syndrome are the fingers and toes, but other regions such as the nose, ears, tongue and nipples have also been reported [14, 15]. The severity and frequency of the symptoms may be more intense in patients with the secondary type of the disease, and also only among this group is the most severe complication - painful digital ulcer (DU) - observed [5].

Raynaud's syndrome is characterized by the co-existence of various medical problems, such as connective tissue, neurological, haematological, infectious diseases, occupational exposure, or as a side effect of pharmacotherapy (Table 1) [16, 17].

A diagnosis of Raynaud's phenomenon may precede the development of connective tissue disease by many years. Alarming symptoms, such as severe Raynaud's phenomenon, presence of autoantibodies, and abnormalities in the nail-fold capillaroscopy (NFC) examination, should lead to identification of an underlying disorder [13].

Nail-fold capillaroscopy is a non-invasive and simple method to assess microcirculation in vivo. The examination is carried out with a bifocal stereomicroscope, but major nailfold capillary abnormalities, such as giant loops, may be visualized with an ophthalmoscope or dermatoscope $[17,18]$. This method is not only used to diagnose Raynaud's phenomenon, but has significant importance to differentiate between primary Raynaud's phenomenon and secondary Raynaud's phenomenon. Primary Raynaud's phenomenon is associated with normal architecture of the capillaries, whereas in secondary Raynaud's phenomenon various abnormalities can be found. The highly specific 'scleroderma pattern' is observed mostly in patients with systemic sclerosis, but also in mixed connective tissue disease and dermatomyositis. It is characterized by the presence of dilated capillaries, haemorrhages, avascular areas and neoangiogenesis. Patients with primary Raynaud's phenomenon with presence of capillary dilations $>30 \mu \mathrm{m}$ are likely to develop systemic sclerosis [19]. The absence of a systemic sclerosis pattern on capillaroscopy has a high negative predictive value $(90 \%)$ for the development of the disease [20]. In more advanced stages of the disease, capillaroscopy might be useful in monitoring the effects of treatment [21] (Figs. 4-6).

Digital thermography of the fingers and toes is another diagnostic tool used to observe the course of Raynaud's phenomenon, even between the vasospastic episodes. This method measures changes in the blood flow caused by the contraction and relaxation of the blood vessels, which directly affects the temperature of the fingers. Some authors recommend nie (niedotlenienie) (ryc. 2) i rumień (faza reperfuzji) (ryc. 3) [1]. Rozpoznanie wymaga obecności co najmniej dwóch następujących po sobie zmian zabarwienia skóry w obrębie palców [9, 12]. Objawu Raynauda nie można rozpoznać u pacjentów, u których występuje wyłącznie faza niedokrwienia [13].

Główną lokalizacją zespołu Raynauda są palce rąk i stóp, choć istnieją również doniesienia o zajęciu nosa, małżowin usznych, języka oraz brodawek sutkowych $[14,15]$. Nasilenie i częstość występowania objawów mogą być wyższe u pacjentów z wtórną postacią choroby. Wyłącznie w tej grupie stwierdza się najcięższe powikłanie - bolesne owrzodzenie palców [5].

Zespół Raynauda rozwija się w przebiegu różnych zaburzeń, takich jak choroby tkanki łącznej, schorzenia neurologiczne i hematologiczne, choroby zakaźne czy narażenie zawodowe. Może być także efektem ubocznym farmakoterapii (tab. 1) [16, 17].

Wystąpienie objawu Raynauda może poprzedzać chorobę tkanki łącznej o wiele lat. Niepokojące objawy, takie jak ciężki objaw Raynauda, obecność autoprzeciwciał oraz nieprawidłowości w badaniu kapilaroskopowym wałów paznokciowych, wskazują na rozwój choroby towarzyszącej [13].

Kapilaroskopia wałów paznokciowych jest prostą i nieinwazyjną metodą oceny mikrokrążenia in vivo. Badanie przeprowadza się za pomocą stereomikroskopu z obiektywem dwuogniskowym, jednak główne nieprawidłowości w obrazie kapilaroskopowym wału paznokciowego, takie jak olbrzymie pętle włośniczek, można wykryć, wykorzystując oftalmoskop lub dermatoskop $[17,18]$. Metoda ta sprawdza się nie tylko w diagnostyce objawu Raynauda, lecz także odgrywa istotną rolę w różnicowaniu pierwotnego i wtórnego objawu Raynauda. U pacjentów z pierwotnym objawem Raynauda obraz naczyń włosowatych nie jest zaburzony, natomiast $\mathrm{u}$ chorych $\mathrm{z}$ wtórnym objawem Raynauda obserwuje się różne odchylenia. Wysoce swoista mikroangiopatia występuje głównie u pacjentów z twardziną układową, ale także z mieszaną chorobą tkanki łącznej i zapaleniem skórno-mięśniowym. Cechuje się obecnością rozszerzonych naczyń włosowatych, występowaniem krwawień, obszarów beznaczyniowych i neoangiogenezy. U pacjentów z pierwotnym objawem Raynauda z rozszerzeniem naczyń włosowatych > $30 \mu \mathrm{m}$ prawdopodobne jest wystąpienie twardziny układowej [19]. Brak mikroangiopatii typowej dla twardziny układowej w obrazie kapilaroskopowym stanowi wysoką negatywną wartość predykcyjną (90\%) rozwoju tej choroby [20]. W bardziej zaawansowanych stadiach choroby kapilaroskopia może być przydatna do monitorowania efektów leczenia [21] (ryc. 4-6).

Kolejnym narzędziem stosowanym w obserwacji przebiegu objawu Raynauda - także pomiędzy kolejnymi epizodami skurczu naczyń - jest obrazowanie 
Table I. Causes of secondary Raynaud's phenomenon $[16,17]$

Tabela I. Przyczyny wtórnego objawu Raynauda [16, 17]

Category/Kategoria

connective tissue diseases/
choroby tkanki tącznej

neurologic diseases/ choroby neurologiczne

haematological diseases/ choroby hematologiczne

\begin{tabular}{|c|c|}
\hline & \\
\hline & mono- and polyclonal cryoglobulinaemia/ krioglobulinemia monoklonalna i poliklonalna \\
\hline & cold agglutinin disease/choroba zimnych aglutynin \\
\hline & hepatitis B and hepatitis C/wirusowe zapalenie wątroby typu B i C \\
\hline 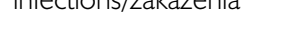 & leprosy/trąd \\
\hline & vibration and mechanical injury/wibracje i urazy mechaniczne \\
\hline occupational exposure/ & lead, thallium, vinyl chloride/ołów, tal, chlorek winylu \\
\hline & chronic effects of cold/przewlekłe skutki narażenia na zimno \\
\hline & $\beta$-blockers $/ \beta$-adrenolityki \\
\hline & ergot alkaloids/alkaloidy sporyszu \\
\hline medicines/leki & cytotoxic drugs (mainly bleomycin)/leki cytotoksyczne (głównie bleomycyna) \\
\hline & interferon- $\alpha$ and interferon- $\gamma /$ interferon $\alpha$ i interferon $\gamma$ \\
\hline & oral contraceptives/doustne środki antykoncepcyjne \\
\hline & $\begin{array}{l}\text { neoplasms (paraneoplastic acral syndrome)/nowotwory (zespół paraneoplastyczny umiejscowiony } \\
\text { na kończynach) }\end{array}$ \\
\hline miscellaneous/pozostałe & injuries/urazy \\
\hline & hypothyroidism/niedoczynność tarczycy \\
\hline & eating disorders/zaburzenia odżywiania \\
\hline
\end{tabular}

systemic sclerosis/twardzina układowa

rheumatoid arthritis/reumatoidalne zapalenie stawów

systemic lupus erythematosus/toczeń rumieniowaty układowy

Sjögren's syndrome/zespół Sjögrena

dermatomyositis/zapalenie skórno-mięśniowe

mixed connective tissue disease/mieszana choroba tkanki łącznej

polymyositis/zapalenie wielomięśniowe

polyarteritis nodosa/guzkowe zapalenie tętnic

arteritis/zapalenie tętnic

atherosclerosis/miażdżyca

vascular diseases/choroby naczyń Buerger's disease/choroba Buergera

Behcet's disease/choroba Behceta

granulomatosis with polyangiitis/ziarniniakowatość z zapaleniem naczyń

Takayasu's disease/choroba Takayasu

carpal tunnel syndrome/zespół cieśni kanału nadgarstka

thoracic outlet syndrome/zespół górnego otworu klatki piersiowej

syringomyelia/jamistość rdzenia

multiple sclerosis/stwardnienie rozsiane

disc prolapsed/wypadnięcie krążka międzykręgowego

disseminated intravascular coagulation/zespół rozsianego wykrzepiania wewnątrznaczyniowego

primary thrombocythemia/nadpłytkowość pierwotna

polycythemia/czerwienica

multiple myeloma/szpiczak mnogi

leukaemias and lymphomas/białaczki i chłoniaki 


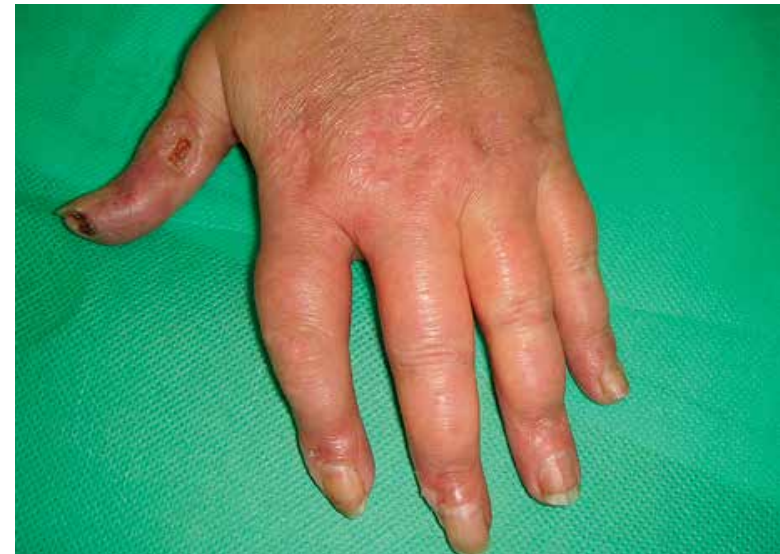

Figure 4. Digital ulcer of the left thumb in female patient with systemic sclerosis

Rycina 4. Dystalne owrzodzenie lewego kciuka u pacjentki z rozpoznanq twardzinq układowa

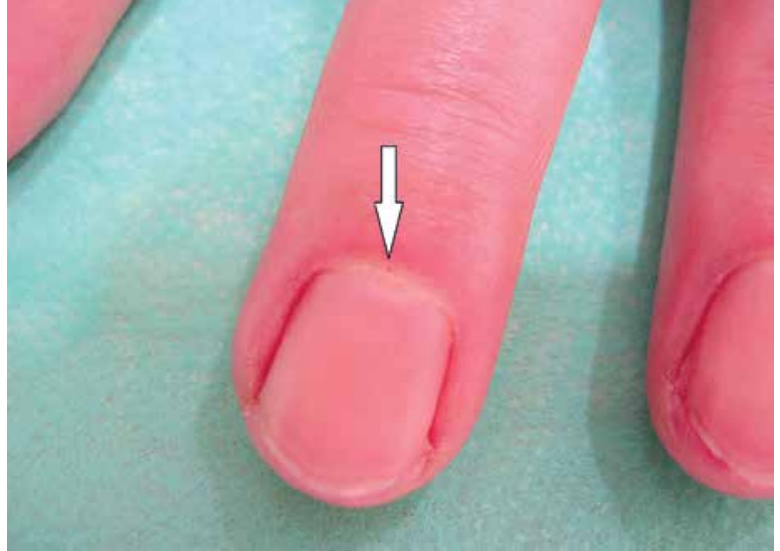

Figure 5. Female patient, with Raynaud's syndrome, diagnosed with scleroderma. $2^{\text {nd }}$ finger of left hand with marked point of capillaroscopy examination

Rycina 5. Pacjentka z zespołem Raynauda ze zdiagnozowang twardzinq układową. Palec drugi ręki lewej z zaznaczonym miejscem badania kapilaroskopowego

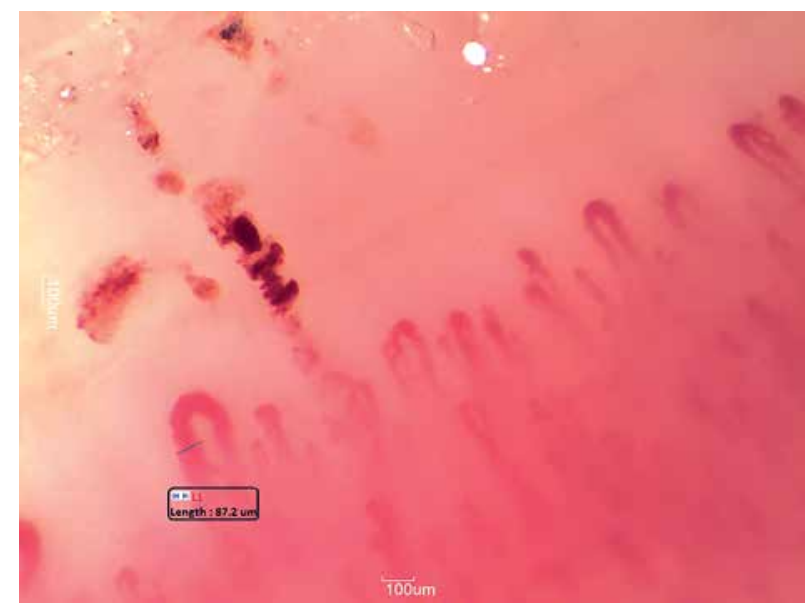

Figure 6. The same female patient, with Raynaud's syndrome, diagnosed with scleroderma. Capillaroscopy picture. Many irregularly enlarged and some giant capillaries can be seen

Rycina 6. Pacjentka z zespołem Raynauda ze zdiagnozowana twardzinq układowq. Zdjęcie obrazu kapilaroskopowego. Widoczne sq liczne nieregularne, powiększone, a miejscami ogromne kapilary thermography to assess Raynaud's phenomenon of the toes, especially among women [22].

An obligatory step in the diagnosis of secondary Raynaud's phenomenon is the analysis of serum ANA titres. Antinuclear antibodies with anti-centromere specificity are associated with a high risk of developing systemic sclerosis. In addition, the interdependence of the occurrence of antibody against PM/Scl-75 and Raynauld's disease, and also presence of the antibody against PM/Scl-100 in patients with systemic sclerosis, has been described [13]. Interestingly, SS-A/ Ro 52 is the most frequently detected antibody in the plasma of patients with Raynaud's phenomenon, but its presence is not related to any other clinical manifestation, apart from the skin involvement [13]. termiczne (termografia) palców dłoni i stóp. Metoda opiera się na pomiarach zmian w przepływie krwi wywołanych skurczem i rozkurczem naczyń krwionośnych, które bezpośrednio wpływają na temperaturę palców. Niektórzy autorzy zalecają termografię przy ocenie objawu Raynauda w obrębie palców stóp, zwłaszcza u kobiet [22].

Obowiązkowym badaniem w diagnostyce wtórnego objawu Raynauda jest oznaczenie miana ANA w surowicy. Istnieje zależność między obecnością ANA o swoistości antycentromerowej a istotnie podwyższonym ryzykiem wystąpienia twardziny układowej. Opisywano związek między występowaniem przeciwciał przeciwko PM/Scl-75 i chorobą Raynauda, a także obecnością przeciwciał przeciwko 


\section{MANAGEMENT OF RAYNAUD'S} PHENOMENON

Treatment used in Raynaud's phenomenon depends on the severity of symptoms and the patient's comorbidities. However, regardless of these circumstances, non-pharmacological therapy is advised to each patient [17]. Avoiding low temperature is the most important preventive behaviour. Avoidance of stress and vasoconstrictive agents, such as nicotine, caffeine, beta-blockers and amphetamines, may have an additional positive effect [16].

Decreasing the frequency and intensity of vasoconstriction episodes is a crucial aim of pharmacological therapy of Raynaud's phenomenon [23].

Calcium channel blockers (CCB) such as nifedipine, diltiazem, and verapamil are the most common medicaments prescribed for Raynauld's disease. These drugs are also the first line of treatment for patients with Raynaud's syndrome and co-occurring systemic sclerosis [24]. The most effective in this case are nifedipine and amlodipine [25]. However, according to the published data, the use of CCB is associated with a number of adverse events, including flushing, headaches, and ankle swelling [24].

Angiotensin convertase enzyme (ACE) inhibitors are another group of drugs used in Raynaud's phenomenon. Captopril improves the cutaneous blood flow, yet the treatment is not associated with a reduction in the severity of symptoms or frequency of vasospastic attacks. Quinapril and enalapril do not show any therapeutic activity for Raynaud's phenomenon [23].

Other medications used in Raynaud's phenomenon treatment include $\alpha 1$-adrenergic blockers. They block the release of norepinephrine, thus preventing vasoconstriction. Prazosin greatly reduces the number of recurrent symptoms in both primary and secondary Raynaud's phenomenon. Long-acting forms of prazosin include doxazosin and terazosin, effective in the treatment of Raynaud's phenomenon by decreasing the number, intensity and duration of vasoconstriction episodes. The side effects which might be observed during $\alpha 1$-adrenergic blocker therapy include orthostatic hypotension, dizziness and asthenia [23].

Digital ulcer is a dangerous complication of Raynaud's phenomenon, and therefore requires more advanced therapy [25].

Phosphodiesterase 5 (PDE 5) inhibitors, such as sildenafil, vardenafil and tadalafil, have been studied in clinical trials that recruited patients diagnosed with digital ulcer or refractory Raynaud's phenomenon [23]. By increasing the level of cGMP, which leads to dilatation of the vessel wall, they significantly reduce the frequency and daily dura-
PM/Scl-100 u pacjentów z twardziną układową [13]. Interesujący jest fakt, że SS-A/Ro 52 jest najczęściej wykrywanym typem przeciwciał w osoczu pacjentów z objawem Raynauda, jednak ich obecność nie wiąże się z żadnym innym objawem poza zajęciem skóry [13].

\section{POSTĘPOWANIE W PRZYPADKACH OBJAWU RAYNAUDA}

Leczenie objawu Raynauda zależy od nasilenia objawów i chorób współistniejących. Niezależnie od tych czynników w każdym przypadku zaleca się jednak leczenie niefarmakologiczne [17]. W ramach zapobiegania czynnikom nasilającym dolegliwość wskazane jest przede wszystkim unikanie narażenia na zimno. Pozytywne skutki przynosi również unikanie stresu oraz substancji powodujących skurcz naczyń, takich jak nikotyna, kofeina, leki $\beta$-adrenolityczne i produkty z grupy amfetamin [16].

Istotnym celem leczenia farmakologicznego objawu Raynauda jest zmniejszenie nasilenia i częstości występowania epizodów skurczu naczyń krwionośnych [23].

W terapii choroby Raynauda najczęściej stosuje się leki z grupy antagonistów wapnia, m.in. nifedypinę, diltiazem i werapamil. Są one również wykorzystywane jako leki pierwszego wyboru u pacjentów z zespołem Raynauda i współistniejącą twardziną układową [24]. Najwyższą skuteczność w takich przypadkach mają nifedypina i amlodypina [25]. Jak wskazują jednak dane $z$ piśmiennictwa, leczenie antagonistami wapnia wiąże się z licznymi działaniami niepożądanymi, m.in. uderzeniami gorąca, bólami głowy i obrzękiem stawów skokowych [24].

Inną grupą leków stosowaną w terapii objawu Raynauda są inhibitory konwertazy angiotensyny (ACE). Kaptopryl poprawia ukrwienie skóry, ale nie obniża częstości występowania napadów skurczu naczyń i nie zmniejsza nasilenia objawów. Kwinapryl i enalapryl nie wykazują żadnej aktywności terapeutycznej w objawie Raynauda [23].

W objawie Raynauda stosuje się także inhibitory receptorów $\alpha 1$-adrenergicznych. Leki te blokują uwalnianie norepinefryny, co zapobiega skurczowi naczyń krwionośnych. Prazosyna znacznie ogranicza nawracające objawy w przebiegu zarówno pierwotnego, jak i wtórnego objawu Raynauda. Postacie prazosyny o przedłużonym działaniu, m.in. doksazosyna i terazosyna, wykazują skuteczność w objawie Raynauda poprzez ograniczanie liczby, nasilenia i czasu trwania epizodów skurczu naczyń. Podczas leczenia inhibitorami receptorów $\alpha 1$-adrenergicznych mogą występować działania niepożądane, m.in. hipotensja ortostatyczna, zawroty głowy i astenia [23]. 
tion of ischaemic attacks in the group of patients with Raynaud's phenomenon. Although the results of the studies were promising, PDE 5 inhibitors have not been approved by the US Food and Drug Administration (FDA) for the treatment of digital ulcer [25].

Prostacyclin analogues, which are potent vasodilators, are also recommended in digital ulcer therapy. A well-known substance in that group is iloprost, which is approved in European countries for the treatment of digital ulcer associated with scleroderma. Iloprost has a dual action: vasodilating and inhibiting activity of blood platelets [25]. Studies have shown that iloprost reduces the frequency, severity, and duration of Raynaud's phenomenon, and also improves the healing of ischaemic ulcers [23]. However, higher doses increase toxicity, which may limit its widespread use [23].

Medicines useful in therapy of digital ulcer also include endothelin derivatives such as bosentan, which is prescribed for patients with pulmonary hypertension, and is additionally approved in Europe for the prevention of digital ulcer in scleroderma [25]. In the RAPIDS-2 trial, bosentan was found to significantly decrease the incidence of new digital ulcers in patients with scleroderma [23]. It can be an alternative for patients with contraindications to prostanoids [26].

Nitrates may be applied for treatment of digital ulcer, but their use is limited by prevalent side effects such as primary hypotension and headaches. Topical nitrates in the form of $2 \%$ nitroglycerine ointment [23] or $0.2 \mathrm{mg} / \mathrm{h}$ patches, applied daily, for $12 \mathrm{~h}$, for 1 week, reduce the frequency and severity of Raynaud's phenomenon onset [25].

Antioxidants such $N$-acetylcysteine, which have potential effects on smooth muscle vasodilation and platelet inhibition, are an interesting group of drugs [25]. In some studies $N$-acetylcysteine reduced the frequency and severity of Raynaud's syndrome [27].

Positive results of treatment with statins were observed in patients with systemic sclerosis-related Raynaud's phenomenon [27].

Additional forms of therapy which protect the affected skin and prevent further risk of microtrauma are wet soaks and occlusive dressing. Application of vitamin E gel shortens the time of healing in scleroderma patients with digital ulcer. Furthermore, regular debridement of necrotic tissue helps to avoid systemic infection and promotes ulcer healing. In case of infection, systemic antibiotic treatment may be necessary [25].

Surgical and other invasive therapies for Raynaud's phenomenon are recommended only for the most severe cases, after unsuccessful attempts of other forms of therapy [23]. One of them is sympathec-
Groźnym powikłaniem w objawie Raynauda jest owrzodzenie palców, które wymaga zaawansowanego leczenia [25].

W badaniach $\mathrm{z}$ udziałem pacjentów z owrzodzeniem palców lub opornym na leczenie objawem Raynauda oceniano inhibitory fosfodiesterazy 5 (PDE 5), takie jak sildenafil, wardenafil i tadalafil [23]. Poprzez podwyższanie poziomu cGMP, które prowadzi do rozszerzenia ściany naczyń krwionośnych, leki te istotnie zmniejszają częstość występowania i dzienny czas trwania napadów niedokrwiennych u pacjentów z objawem Raynauda. Choć badania przyniosły obiecujące wyniki, inhibitory PDE 5 nie zostały zatwierdzone przez Amerykańską Agencję ds. Żywności i Leków (FDA) w leczeniu owrzodzeń palców [25].

Inną grupą leków zalecanych w terapii owrzodzeń palców są analogi prostacykliny. Dobrze znanym preparatem $\mathrm{z}$ tej grupy jest iloprost zarejestrowany w krajach europejskich w leczeniu owrzodzeń palców w przebiegu twardziny. Iloprost działa dwutorowo - rozszerza naczynia krwionośne oraz hamuje aktywność płytek krwi [25]. Badania wykazały, że iloprost zmniejsza częstość, nasilenie i czas trwania objawu Raynauda, a także sprzyja gojeniu owrzodzeń niedokrwiennych [23]. Wraz ze wzrostem dawki iloprostu występuje jednak efekt toksyczny, który może ograniczać szerokie stosowanie leku [23].

Korzyści w terapii owrzodzeń palców przynoszą pochodne endoteliny, takie jak bozentan stosowany $\mathrm{u}$ pacjentów $\mathrm{z}$ nadciśnieniem płucnym. Lek ten jest również zarejestrowany w Europie w profilaktyce owrzodzeń palców w przebiegu twardziny [25]. W badaniu RAPIDS-2 wykazano, że istotnie zmniejsza on częstość występowania nowych owrzodzeń palców u pacjentów z twardziną [23]. Bozentan może być stosowany jako lek alternatywny u pacjentów z przeciwwskazaniami do leczenia prostanoidami [26].

Owrzodzenia palców można także leczyć azotana$\mathrm{mi}$, lecz ich stosowanie jest ograniczone ze względu na powszechnie występujące skutki uboczne, w tym hipotensję pierwotną i bóle głowy. Częstość występowania napadów objawu Raynauda i ich nasilenie zmniejszają również miejscowe azotany w postaci maści nitroglicerynowej 2\% [23] lub plastrów transdermalnych $0,2 \mathrm{mg} / \mathrm{h}$ stosowane codziennie przez 12 godzin przez 1 tydzień [25].

Związki o działaniu przeciwutleniającym, np. $N$-acetylocysteina, mogą wpływać na rozszerzanie naczyń krwionośnych mięśni gładkich i hamowanie płytek krwi [25]. W niektórych badaniach wykazano, że $N$-acetylocysteina zmniejsza częstość występowania i nasilenie zespołu Raynauda [27].

Pozytywne efekty leczenia statynami obserwowano również u pacjentów z objawem Raynauda w przebiegu twardziny układowej [27].

Inne metody ochrony zajętej skóry i zapobiegania mikrourazom to mokre okłady oraz opatrunki 
tomy (blockage of the nerves causing vasculopathy) [28]. This method may be effective in some patients with critical ischaemia of the digits, principally to relieve pain [23]. Studies have shown [23, 25] that digital sympathectomies are well tolerated and may lead to a significant clinical improvement in the treatment of pre-existing ulcers and function of the hand [25].

Some scientific reports mention $[25,29-31]$ the benefits of the use of botulinum toxin A (BTX-A) in patients with digital ischaemia with or without ulceration [25]. The probable mechanism of action of BTX-A is increasing blood flow and reducing pain, by blocking the effect of the sympathetic nervous system [29]. BTX-A injections, as a less invasive treatment, with a low rate of complications, can be a good alternative for cases of Raynaud's phenomenon unresponsive to other forms of therapy [30].

Recent research has suggested that autologous fat grafting may be a promising method for patients with severe symptoms of Raynaud's syndrome such as digital ulcers. The effective mechanism for such therapy requires the presence of adipose-derived stem cells, which secrete cytokines of a favourable profile that promotes neovascularisation [32].

Digital amputation may be necessary for the most severe cases of Raynaud's phenomenon with significantly disturbed healing, accompanied by pain or infection [25].

To sum up, diagnosis and treatment of Raynaud's phenomenon remain a challenge, mainly due to the complex aetiopathogenesis, as well as the diverse symptoms of RS. Therefore, gaining a better understanding of the pathophysiology and selection of appropriate treatment seem to be the main directions of research in this area.

\section{CONFLICT OF INTEREST}

The authors declare no conflict of interest. okluzyjne. Stosowanie żelu z witaminą E skraca czas leczenia pacjentów z twardziną oraz towarzyszącymi jej owrzodzeniami palców. Regularne usuwanie tkanek martwiczych pomaga uniknąć zakażenia ogólnoustrojowego i sprzyja leczeniu owrzodzeń. W przypadku zakażenia konieczne może być wdrożenie antybiotykoterapii ogólnoustrojowej [25].

Leczenie chirurgiczne oraz inne inwazyjne metody zaleca się wyłącznie w najcięższych przypadkach objawu Raynauda, po niepowodzeniu innych terapii [23]. Jedną z nich jest sympatektomia, która polega na blokadzie nerwów odpowiedzialnych za waskulopatię [28]. Metoda ta może być skuteczna u niektórych pacjentów z krytycznym niedokrwieniem palców, głównie w łagodzeniu dolegliwości bólowych [23]. W badaniach [23, 25] wykazano, że sympatektomia palców jest zabiegiem dobrze tolerowanym i zapewnia istotne korzyści kliniczne pod względem leczenia powstających owrzodzeń oraz poprawy czynności ręki [25].

Niektóre prace $[25,29-31]$ wskazują na korzyści ze stosowania toksyny botulinowej (BTX-A) u pacjentów z niedokrwieniem palców, zarówno z towarzyszącym owrzodzeniem, jak i bez tego objawu [25]. Mechanizm działania BTX-A opiera się prawdopodobnie na zwiększaniu przepływu krwi i ograniczaniu bólu poprzez blokowanie oddziaływania układu współczulnego [29]. Iniekcje BTX-A są mniej inwazyjną metodą leczenia o niskim wskaźniku powikłań i stanowią skuteczną terapię alternatywną w przypadkach objawu Raynauda niereagujących na inne formy leczenia [30].

Najnowsze badania wskazują, że obiecującą metodą terapii pacjentów z ciężkimi objawami zespołu Raynauda, takimi jak owrzodzenia palców, może być autologiczny przeszczep tkanki tłuszczowej. Aby metoda ta była skuteczna, wymagane są komórki macierzyste pochodzące z tkanki tłuszczowej, które cechują się korzystnym profilem cytokinowym sprzyjającym neowaskularyzacji [32].

W najcięższych przypadkach objawu Raynauda o istotnie zaburzonym procesie gojenia, któremu towarzyszy ból lub zakażenie, konieczna jest amputacja palców [25].

Podsumowując - diagnostyka i leczenie objawu Raynauda nadal stanowią wyzwanie, głównie ze względu na złożoną etiopatogenezę oraz szerokie spektrum objawów zespołu Raynauda. Badania w tej dziedzinie są ukierunkowane głównie na dokładne poznanie patofizjologii schorzenia oraz dobór właściwej metody leczenia.

\section{KONFLIKT INTERESÓW}

Autorzy deklarują brak konfliktu interesów. 


\section{References}

Piśmiennictwo

1. Raynaud M.: Local asphyxia and symmetrical gangrene of the extremities 1862. New researches on the nature and treatment of local asphyxia of the extremities 1874. Translated by Barlow. London: New Sydenham Society, 1888.

2. Lewis T.: Experiments relating to the peripheral mechanism involved in spasmodic arrest of the circulation in the fingers, a variety of Raynaud's disease. Heart 1929, 15, 7-101.

3. Weller R.B.: Disorders of blood vessels and lymphatics. In: Clinical Dermatology. R.B. Weller, H.J.A. Hunter, W. Margaret, M.W. Mann (eds.). Wiley-Blackwell, Chichester, 2015, 143-144.

4. Block J.A., Sequeira W.: Raynaud's phenomenon. Lancet 2001, 357, 2042-2048.

5. Goundry B., Bell L., Langtree M., Moorthy A.: Diagnosis and management of Raynaud's phenomenon. BMJ 2012, 344, e289.

6. Garner R., Kumari R., Lanyon P., Doherty M., Zhang W.: Prevalence, risk factors and associations of primary Raynaud's phenomenon: systematic review and meta-analysis of observational studies. BMJ Open 2015, 5, e006389.

7. Pope J.E.: Raynaud's phenomenon (primary). BMJ Clin Evid 2011, 1119.

8. Herrick A.L.: Pathogenesis of Raynaud's phenomenon. Rheumatology (Oxford) 2005, 44, 587-596.

9. Maverakis E., Patel F., Kronenberg D.G., Chung L., Fiorentino D., Allanore Y., et al.: International consensus criteria for the diagnosis of Raynaud's phenomenon. J Autoimmn 2014, 48-49, 60-65.

10. Giurgea G.A., Mlekusch W., Charwat-Resl S., Mueller M., Hammer A., Gschwandtner M.E., et al.: Relationship of age and body mass index to skin temperature and skin perfusion in primary Raynaud's phenomenon. Arthritis Rheum 2015, 67, $238-242$.

11. Roquelaure Y., Ha C., Le Manac'h A.P., Bodin J., Bodere A., Bosseau C., et al.: Risk factors for Raynaud's phenomenon in the workforce. Arthritis Care Res (Hoboken) 2012, 64, 898-904.

12. Wigley F.M., Flavahan N.A.: Raynaud's phenomenon. N Engl J Med 2002, 347, 1001-1008.

13. Ingegnoli F., Gualtierotti R., Orenti A., Schioppo T., Marfia G., Campanella R., et al.: Uniphasic blanching of the fingers, abnormal capillaroscopy in nonsymptomatic digits, and autoantibodies: expanding options to increase the level of suspicion of connective tissue diseases beyond the classification of Raynaud's phenomenon. J Immunol Res 2015, 2015, 371960.

14. Ghiam A.F., Cho J.: Lingual Raynaud phenomenon. CMAJ 2015, 187, 1160.

15. Wu M., Chason R., Wong M.: Raynaud's phenomenon of the nipple. Obstet Gynecol 2012, 119, 447-449.

16. Kaufmann R.: Functional angiopathies. In: Braun-Falco's Dermatology. W. Burgdorf, G. Plewig, H.H. Wolff, M. Landthaler (eds.). Springer, Berlin, 2009, 865-866.

17. Maricq H.R., LeRoy E.C.: Patterns of finger capillary abnormalities in connective tissue disease by "wide-field" microscopy. Arthritis Rheum 1973, 16, 619-628.

18. Bauersachs R.M., Lossner F.: The poor man's capillary microscope. A novel technique for the assessment of capillary morphology. Ann Rheum Dis 1997, 56, 435-437.

19. Trombetta C., Smith V., Pizzorni C., Meroni M., Paolino S., Cariti C., et al.: Quantitative alterations of capillary diameter have a predictive value for development of the capillaroscopic systemic sclerosis pattern. J Rheumatol 2016, 43, 599-606.

20. Bissell L.A., Abignano G., Emery P., Del Galdo F., Buch M.H.: Absence of scleroderma pattern at nail fold capillaroscopy valuable in the exclusion of scleroderma in unselected patients with Raynaud's phenomenon. BMC Musculoskelet Disord 2016, 17, 342.

21. Hughes M., Moore T., O'Leary N., Tracey A., Ennis H., Dinsdale G., et al.: A study comparing videocapillaroscopy and dermoscopy in the assessment of nailfold capillaries in patients with systemic sclerosis-spectrum disorders. Rheumatology 2015, 54, 1435-1442.

22. Lim M.J., Kwon S.R., Jung K.H., Joo K., Park S.G., Park W.: Digital thermography of the fingers and toes in Raynaud's phenomenon. J Korean Med Sci 2014, 29, 502-506.

23. Landry G.J.: Current medical and surgical management of Raynaud's syndrome. J Vasc Surg 2013, 57, 1710-1716.

24. Ennis H., Hughes M., Anderson M.E., Wilkinson J., Herrick A.L.: Calcium channel blockers for primary Raynaud's phenomenon. Cochrane Database Syst Rev 2016, 2, CD002069.

25. Abraham S., Steen V.: Optimal management of digital ulcers in systemic sclerosis. Ther Clin Risk Manag 2015, 11, 939-947.

26. Parisi S., Bruzzone M., Centanaro Di Vittorio C., Laganà A., Peroni C.L., Fusaro E.: Efficacy of bosentan in the treatment of Raynaud's phenomenon in patients with systemic sclerosis never treated with prostanoids. Reumatismo 2014, 65, 286-291.

27. Levien T.L.: Advances in the treatment of Raynaud's phenomenon. Vasc Health Risk Manag 2010, 6, 167-177.

28. Momeni A., Sorice S.C., Valenzuela A., Fiorentino D.F., Chung L., Chang J.: Surgical treatment of systemic sclerosis - is it justified to offer peripheral sympathectomy earlier in the disease process? Microsurgery 2015, 35, 441-446.

29. Zhao H., Lian Y.: Clinical and image improvement of Raynaud's phenomenon after botulinum toxin type A treatment. Australas J Dermatol 2015, 56, 202-205.

30. Żebryk P., Puszczewicz M.J.: Botulinum toxin A in the treatment of Raynaud's phenomenon: a systematic review. Arch Med Sci 2016, 12, 864-870.

31. Zhang X., Hu Y., Nie Z., Song Y., Pan Y., Liu Y., et al.: Treatment of Raynaud's phenomenon with botulinum toxin type A. Neurol Sci 2015, 36, 1225-1231.

32. Granel B., Daumas A., Jouve E., Harlé J.R., Nguyen P.S., Chabannon C., et al.: Safety, tolerability and potential efficacy of injection of autologous adipose-derived stromal vascular fraction in the fingers of patients with systemic sclerosis: an open label phase 1 trial. Ann Rheum Dis 2014, 74, 2175-2182.

Received: 6.04.2017

Accepted: 21.09.2017

Otrzymano: 6.04.2017 r.

Zaakceptowano: $21.09 .2017 \mathrm{r}$.

How to cite this article

Górska K., Szczerkowska-Dobosz A., Purzycka-Bohdan D., Stawczyk-Macieja M., Wierzba K., Nowicki R.J.: Raynaud's phenomenon as an interdisciplinary problem. Przegl Dermatol/Dermatol Rev 2017, 104, 499-508. DOI: https://doi.org/10.5114/dr.2017.71215. 